\title{
Investigation of The Quality of Domestically Produced Honey, and the Sources, Trends and Quality of the Imported Honey: with Special Reference to Addis Ababa and Surrounding Markets
}

\author{
Hana Tadese, Yeshitila Eshete* and Tigiste Lema \\ Honey and Beeswax Product Processing and Research Department, Ethiopian Meat and Dairy Industry Development Institute, \\ Ethopia
}

*Corresponding author: Yeshitila Eshete, Honey and Beeswax Product Processing and Research Department, Ethiopian Meat and Dairy Industry Development Institute, Ethopia

\section{ARTICLE INFO}

Received: 幽 December 05, 2020

Published: 㗀 December 21, 2020

Citation: Hana Tadese, Yeshitila Eshete, Tigiste Lema. Investigation of The Quality of Domestically Produced Honey, and the Sources, Trends and Quality of the Imported Honey: with Special Reference to Addis Ababa and Surrounding Markets. Biomed J Sci \& Tech Res 32(4)-2020. BJSTR. MS.ID.005289.

Keywords: HMF; Quality; Honey; Adulteration; Dehydrate

Abbreviations: LC: Liquid Chromatography; GC: Gas Chromatography; NH: Natural Honey

\section{ABSTRACT}

This study has needed to investigate the quality, origin, legality, and authenticity of honey imported to Ethiopia and the trends in the importation across the year. For the study three towns (Addis Ababa, Adama and Bishoftu) were selected with purposive sampling method. It was collected from 12 major supermarkets found in Addis, Bishoftu and Adama towns which can represent the potential areas of honey seller super markets in these towns. The entire collected sample weighted $0.5 \mathrm{~kg}$ and ten of the honey samples were from local honey and the other two sample were imported honey from India and UAE. The samples were categorized into local honey and imported honey. After categorizing the collected sample the sample taken to Ethiopian Conformity Assessment Laboratory for testing for Moisture content, sugar and HMF test parameters. The collected data's were analyzed using simple descriptive statistics method and some figures were interpreted using graphs. all the tested sample ranged from 15.6\%-22\% with the mean value moisture content $18.8 \%$.Sucrose level of the all the collected sample were $<0.1 \%$ the values obtained for sucrose contents of the honey samples in this study were all within the limits of national and international standards. However, Out of the twelve tasted samples only three of the sample meets the international and national HMF content standards but nine of the sample fails to meet the standard requirement which is $40 \mathrm{mg} / \mathrm{kg}$ mainly due to inappropriate heating of honey in high temperature and prolonged storage [1-3].

The study concludes that to develop consumers confidence and also to encourage local honey producers and processors the study recommended that the concerned regulatory bodies should to set the regulatory mechanisms and implement integrated with the relevant organizations along at all levels. Processing industries should process honey by adjusting the temperature of the processing Machine when the moisture content is high or, conversely, by decreasing the temperature when the moisture content is low. Because long storage periods lead to high HMF formation in honey shortening the storage period can reduce the formation of HMF. Reduced thermal input can also be achieved by heating honey to a low temperature for a prolonged period.

\section{Introduction}

Food quality and safety issues have been major emerging areas within the food supply chain and have attracted a lot of attention from various research, government and regulatory bodies.

Adulteration is the act of either by adding extraneous substances (adulterants) into food items or products or reducing essential nutrients partly or wholly for financial gain or due to carelessness 
and lack of proper hygienic condition during processing, storing, transportation and marketing. Product adulteration is fast growing a worldwide challenging issue that negatively influences market growth by destroying consumer trust. Globalization, growing incomes, population growth, urbanization and rapid rise in living standards and increased awareness on nutritional and health benefits of honey are lead to increase the consumption trends to semi processed and high value agricultural products in many developed and developing countries. Honey authenticity has two different aspects. The first of these is authenticity in terms of its content i.e. that it is 100 percent real natural honey and has not been adulterated with any other products. The second is authenticity concerning its description: geographical and botanical origin. Both A aspects, content and origin are required for honey to be authentic. In addition, honey may have other categories assigned to it, such as organic, fairly traded, unfiltered, raw, etc [4].

According to the standards of Codex Alimentarius (FAO 2001), "honey is the natural sweet substance produced by honeybees from the nectar of plants or from secretions of living parts of plants or excretions of plant-sucking insects on the living parts of plants, which the bees collect, transform by combining with specific substances of their own, deposit, dehydrate, store and leave in the honey comb to ripen and mature [5]. Honey adulteration appeared on the world market in the 1970s when high-fructose corn syrup was introduced by the industry. Honey adulteration is a complex problem which currently has a significant economic impact. There are many methods utilized for honey adulteration detection by most researchers, for instance Gas Chromatography (GC) and Liquid Chromatography (LC) analysis [6]. In the last few decades, owing to its more appreciated flavor and aroma, and also to particular pharmacological attributes, there has been higher consumer demand for natural honey, thus increasing its commercial value [7].

The main concerns related to honey authenticity have been focused on the geographical and botanical origins, but the addition of other non allowed substances, such as syrups or sugars, is also an important issue. Adulteration practices, such as overfeeding the bees with sucrose or other sugars, harvesting prior to maturity, and the overuse of veterinary drugs, are still performed by some producers around the globe to answer to the demands of a competitive market [8-10]. Honeys adulterated by sugar addition can present, in fact, changes in some chemical and/or biochemical parameters, such as enzymatic activity, electrical conductivity, and contents of specific compounds (HMF, glucose, fructose, sucrose,

Table 1: Presents all the results of the physicochemical analysis. maltose, is maltose, proline, ash) when compared to a control [11]. The major concern of honey quality is to ensure that honey is authentic in respect to the legislative requirements. According to the definition of the Codex Alimentarius (Codex Alimentarius Commission 2001) [12], and other international honey standards (2001/110/EC, EU Council 2002) honey shall not have added any food ingredient than honey to it nor shall any particular constituent be removed from it. The use of Natural Honey $(\mathrm{NH})$ and other honeybee products as food and medicine by mankind has been in existence from time immemorial. There comes forth from their bellies, a drink of existence from time immemorial. In fact, records have shown that raw honey is the most ancient sweetener and it was noted to have been in use throughout the world several million years ago . In Ethiopia honey is almost exclusively used for local conception and to a very large extent (80\%) for brewing of mead, locally called 'Tej”.

\section{Problem Statement}

Due to the complex nature of honey and to the different types of vulnerability to adulteration, its authentication has been challenging and prompted the development of several advanced analytical approaches. There is a growing need to assess the authenticity of honey, particularly with regard to quality, geographical and botanical origins. Currently, organoleptic properties, physicochemical analysis, and pollen spectrum are the main criteria for honey classification (Table 1). The demand to the processed and packed honey is increasing due to urbanization, population growth economic development of the community and increased awareness on health benefits of honey. This makes the consumers to lack confidence to buy honey. On the other hand Ethiopia have been exported honey to different countries in the world including USA, Japan, EU, Germany, Norway and others. Between 2011-2016 Ethiopia exported a total of 4252.8 tons of honey to different countries. The developed countries has been setting astringent quality control system and due to this honey export performance is becoming decreasing, and some of the honey samples that tasted were fail to fulfill the quality requirements of the imported countries. Therefore, this research proposal is initiated to evaluate the quality of locally produced and imported honey based on the National and international quality standards and at the mean time to evaluate the, level of adulteration and to indicate quality assurance police development and branding of the products with the following specific objectives.

\begin{tabular}{|c|c|c|c|c|c|c|c|c|c|c|c|c|c|c|}
\hline Parameters & $\begin{array}{l}\text { Standard } \\
\text { requirement }\end{array}$ & $\begin{array}{l}\text { ETHIO- } \\
\text { MAR }\end{array}$ & $\begin{array}{l}\text { TADELE- } \\
\text { MAR }\end{array}$ & $\begin{array}{l}\text { MEKLET- } \\
\text { MAR }\end{array}$ & $\begin{array}{l}\text { NETU- } \\
\text { MAR }\end{array}$ & $\begin{array}{l}\text { VIRGINIA- } \\
\text { mar }\end{array}$ & $\begin{array}{l}\text { Abyssinia } \\
\text { mar }\end{array}$ & $\begin{array}{l}\text { tutu- } \\
\text { mar }\end{array}$ & $\begin{array}{l}\text { tresses- } \\
\text { mar }\end{array}$ & $\begin{array}{l}\text { Herman- } \\
\text { honey }\end{array}$ & $\begin{array}{l}\text { dimma- } \\
\text { honey }\end{array}$ & $\begin{array}{l}\text { keffa- } \\
\text { honey }\end{array}$ & $\begin{array}{l}\text { right- } \\
\text { honey }\end{array}$ & average \\
\hline $\begin{array}{c}\text { Moisture content } \% \text { by } \\
\text { mass }\end{array}$ & $18-22$ & 19.6 & 18.5 & 19.5 & 15.6 & 17.9 & 20.6 & 18 & 18.4 & 17.6 & 17.2 & 21.1 & 22 & 18.8333 \\
\hline $\begin{array}{l}\text { Fructose content } \% \text { by } \\
\text { mass }\end{array}$ & & 32.5 & 33.1 & 44.3 & 35 & 39.2 & 50.5 & 30.1 & 37 & 32.4 & 34.8 & 45.2 & 30.6 & 37 \\
\hline $\begin{array}{l}\text { Glucose content \%by } \\
\text { mass }\end{array}$ & & 36.5 & 38.6 & 27.9 & 39.4 & 32.8 & 22 & 34.4 & 30.8 & 30 & 33.3 & 23.4 & 33.6 & 31.89 \\
\hline
\end{tabular}




\begin{tabular}{|c|c|c|c|c|c|c|c|c|c|c|c|c|c|c|}
\hline $\begin{array}{l}\text { Sucrose content \%by } \\
\text { mass }\end{array}$ & 5 & $<0.1$ & $<0.1$ & $<0.1$ & $<0.1$ & $<0.1$ & $<0.1$ & $<0.1$ & $<0.1$ & $<0.1$ & $<0.1$ & $<0.1$ & $<0.1$ & $<0.1$ \\
\hline $\begin{array}{c}\text { Turanose content \%by } \\
\text { mass }\end{array}$ & & $<0.1$ & $<0.1$ & $<0.1$ & $<0.1$ & $<0.1$ & $<0.1$ & $<0.1$ & $<0.1$ & $<0.1$ & $<0.1$ & $<0.1$ & $<0.1$ & $<0.1$ \\
\hline $\begin{array}{c}\text { Maltose content \%by } \\
\text { mass }\end{array}$ & & $<0.1$ & $<0.1$ & $<0.1$ & $<0.1$ & $<0.1$ & $<0.1$ & $<0.1$ & $<0.1$ & $<0.1$ & $<0.1$ & $<0.1$ & $<0.1$ & $<0.1$ \\
\hline $\begin{array}{l}\text { Hydroxymethylfurfural/ } \\
\text { HMF/ content, mg/kg }\end{array}$ & $40 \mathrm{mg} . \mathrm{kg}$ & 1954.3 & 2106.6 & 7.1 & 899.7 & 100.7 & 36.3 & 1689.7 & 1437 & 47.1 & 24.4 & 464.2 & 943.2 & 809.192 \\
\hline
\end{tabular}

\section{Objectives}

- To investigate the quality, origin, legality, and authenticity of honey imported to Ethiopia and the trends in the importation across the year

\section{Specific objective}

- $\quad$ To evaluate the quality of domestically and imported honey

- To identify extent and level of adulteration

\section{Material and Method}

This research has been conducted with the collection of sample from Addis Ababa, Bishoftu and Adma towns in Ethiopia. It was collected from 12 major supermarkets found in Addis, Bishoftu and Adama towns which can represent the potential areas of honey seller super markets in these towns. The entire collected sample weighted $0.5 \mathrm{~kg}$ and ten of the honey samples were from local honey and the other two sample were imported honey from India and UAE. The samples were categorized into local honey and imported honey.

After categorizing the collected sample the sample taken to Ethiopian Conformity Assessment Laboratory for testing for Moisture content, sugar and HMF test parameters.

\section{Sampling Method}

The sample collection was carried out for seven days by random sampling method .For the study 12 honey sample with an average weight of $0.5 \mathrm{~kg}$ honey collected in different supermarkets. During the sample collection relatively different type of processed honey were purchased.

\section{Quality Analysis of Honey}

For the processed honey physical and chemical quality parameters was analyzed by Ethiopian Conformity Assessment Enterprise (ECAE). The physical and chemical properties that are relevant to honey like moisture content, Sugar content/ sucrose, fructose and glucose/and HMF content were tested. The collected samples were analyzed based on the protocol of the national\& international standard requirement.

\section{Data Management and Statically Analysis}

Descriptive statistics were used to analyses the sample and to compare the mean of the samples.

\section{Result and Discussion}

During the study period the sample collected from different supermarket the prices of honey were varied from place to place. The variation ranges from Birr 160.00/kg to Birr $360 / \mathrm{kg}$ with mean of Birr 260/kg for local honey and for the price for imported honey it was $160 \mathrm{birr} / \mathrm{kg}$. The main reason for rising of price locally processed honey could be due to the price of unprocessed honey high, shortage of quality product in the farm get, manufacturing cost is high and illegal traders.

\section{Moisture Content Analysis}

Moisture in honey is an essential quality criterion in honey processing industries, as the probability of fermentation of honey over storage increases with moisture content. Honey is hygroscopic which means it can easily absorb moisture from the air around it. But, if the air is dry, then honey will lose moisture, thus improving its quality. According to Bogdanov, moisture content gives an indication of the shelf-stability of the product. Higher moisture content therefore directly correlates to early fermentation due to yeast. The moisture content of the all the tested sample ranged from $15.6 \%-22 \%$ with average moisture content 18.8 which meet national and international standards.

\section{Honey Sugar Analysis}

Sucrose level of the all the collected sample were $<0.1 \%$ the values obtained for sucrose contents of the honey samples in this study were all within the limits of national and international standards.

The higher concentration of fructose relative to glucose is one way in which honey differs from commercial invert sugar syrup and in honey of good quality the fructose content should exceed that of glucose. The entire tasted sample the fructose content is lower than the glucose content. Although there are no regulatory limits on individual values of fructose and glucose their sum has been fixed at a value of $\geq 60 \mathrm{~g} / 100 \mathrm{~g}$ as one of the requirements of the international standard for honey established by Codex Alimentarius Commission. The sum of fructose and glucose for the honey samples used in this study all exceeded limit required by the Codex; i.e., $60 \mathrm{~g} / 100 \mathrm{~g}$.

\section{HMF Analysis}

Out of the twelve tasted samples only three of the sample meets the international and national HMF content standards but nine of 
the sample fail to meet the standard requirement which is $40 \mathrm{mg} /$ $\mathrm{kg}$.Among the tested sample that fail to meet the standard HMF requirement tow of them were imported honey from UAE and India on the other hand three honey samples that meet the standard HMF requirement were meklet, dimma and Abyssinia honey. The higher levels of HMF an indicator of heating and storage changes. Even though heating is of great important, no guideline is available till to date for the use of heating temperature and time for a particular type of honey. It is believed that the optimum heating conditions are mainly relied on the geographical and botanical origins of honey. Different origins of honey vary in their biochemical composition. A wide range of heating temperatures ranging from 30 to $140 \mathrm{C}$ for a few seconds up to several hours had been practiced by honey producers worldwide, with the aim to reduce the water content in honey below $20 \%$ for shelf life prolongation.

The development of HMF in honey can be considered as an important freshness and quality indicator, because elevated concentration is a sign for overheating, long time storage in poor conditions or aging of the honey. International honey standards authorities repeatedly used HMF as reliable quality parameters. Enzymes are also used as a quality parameter; even though, some honey do have a lower level of enzymes intrinsically [13-15]. In line with this, HMF level of honey is used to verify, whether the lower level of enzyme is intrinsic or extrinsic characteristic of the honey. The use of HMF and enzyme activity for honey quality determination is firmly rooted in honey quality legislation, and illustrated by the honey standard authorities of the Codex Alimentarius and European Union.

\section{Honey Imported to Ethiopia and the Trends in the Importation Across the Year}

The secondary data obtained from Ethiopian custom and revenue authority indicate that from 2014-2018 12 tone of natural honey imported around the world. As the graph indicate the origin of natural honey imported from south Africa, UAE, Italy, Oman, Spain, Kenya, England ,Saudi Arabia and china The origin of natural honey imported to the country based on the amount Italy is the leading country followed by UAE and South Africa (Graph 1).

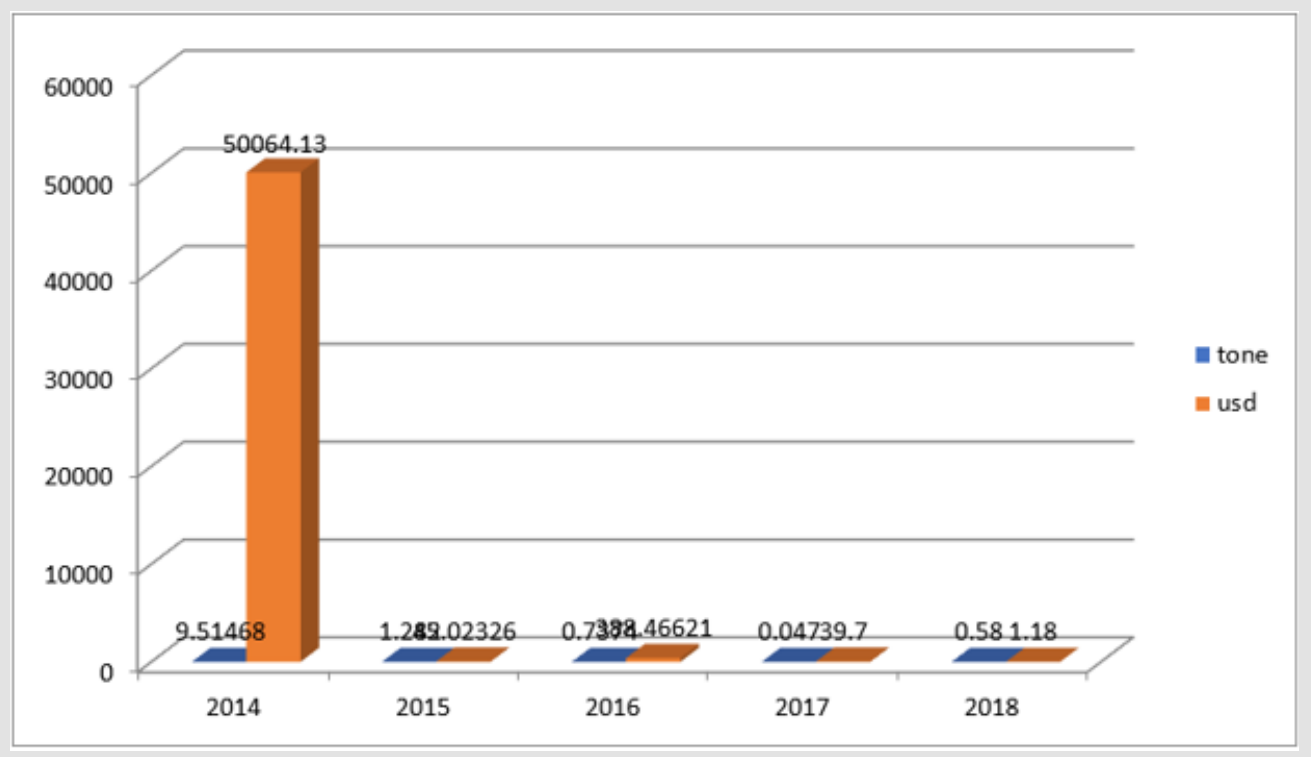

Graph 1: Honey import for the past five years.

\section{Conclusion}

Quality of honey is characterized by three sets of parameters organoleptic properties reflect what can be sensed and described based on sight, taste, smell, and mouth feel. Those are: color aroma, taste and texture. Natural chemical composition of honey is formed by water, glucose, fructose, reducing sugar ,sucrose, protein, enzymes and vitamins content (Graph 2). Level of chemical contamination caused by residual antibiotics, pesticides and heavy metals. Added sugars like HFCS or artificial sweeteners can also be measured. According to this study the moisture content of the all the tested sample ranged from $15.6 \%-22 \%$ with the mean value moisture content $18.8 \%$.Sucrose level of the all the collected sample were $<0.1 \%$ the values obtained for sucrose contents of the honey samples in this study were all within the limits of national and international standards. However, Out of the twelve tasted samples only three of the sample meets the international and national HMF content standards but nine of the sample fails to meet the standard requirement which is $40 \mathrm{mg} / \mathrm{kg}$ mainly due to inappropriate heating of honey in high temperature and prolonged storage. From 2014-2018 the country imported 12 tons of natural honey around the world and the origin of natural honey imported to the country based on the amount Italy is the leading country followed by UAE and South Africa. 


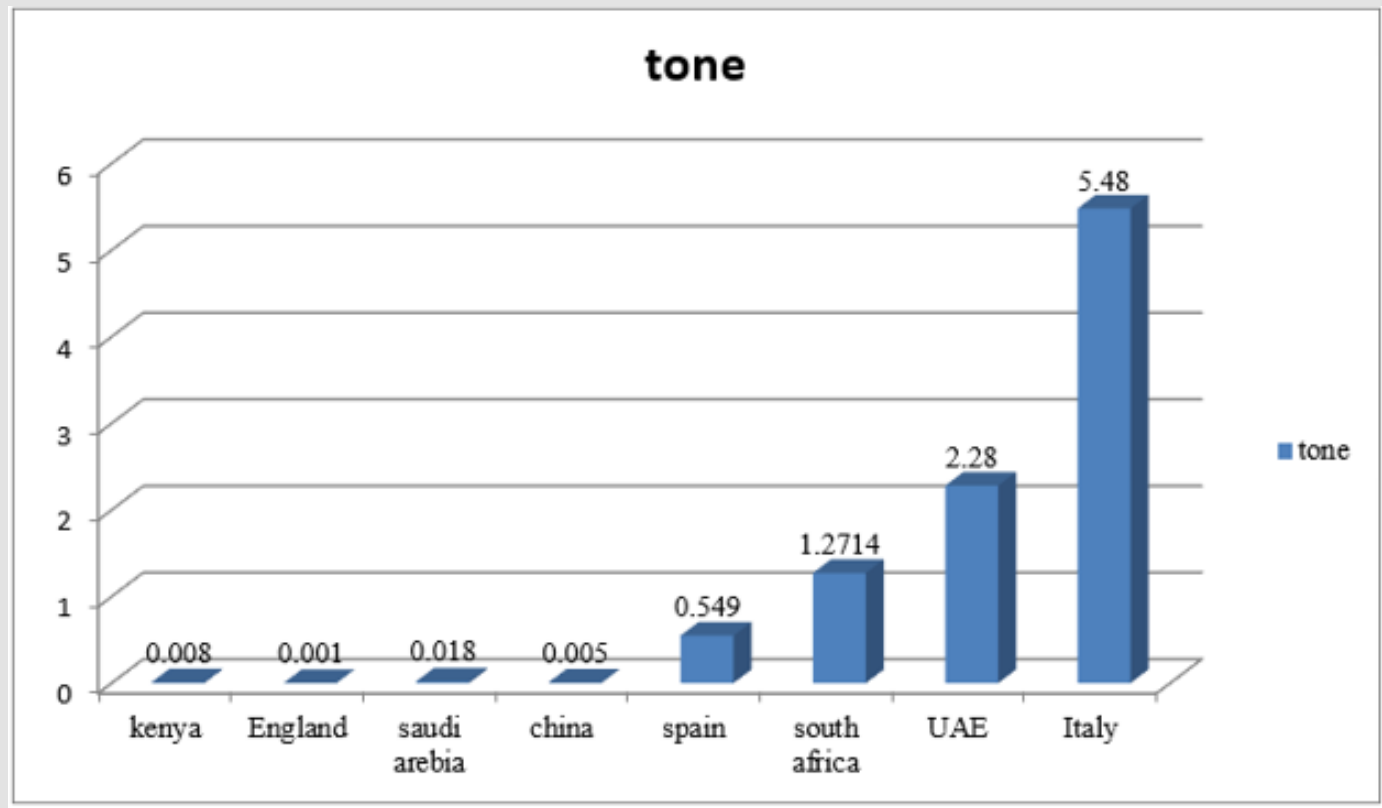

Graph 2: Country Honey imported from for the past five years.

\section{Recommendations}

a) EMDIDI AND MOLF should work together to put in place and implement beehive products marketing and quality administration and regulation mechanism.

b) Creating awareness to the concerned stakeholders across the value chain on the regulation of imported honey

c) Honey and other bee-hive products inspection, sampling, tasting and certification bodies in particular to import and export should to have developed integrated service provision systems.

d) Processing industries should process honey by adjusting the temperature of the processing oven when the moisture content is high or, conversely, by decreasing the temperature when the moisture content is low.

e) Because long storage periods lead to high HMF formation in honey shortening the storage period can reduce the formation of HMF.

f) Reduced thermal input can also be achieved by heating honey to a low temperature for a prolonged period

\section{Acknowledgment}

We would like to acknowledge Ethiopian Meat and Dairy Industry Development Institute, for the required logistics facilitation to carry out the study and Our appreciation extended to Ethiopian Conformity Assessment Enterprise, Ethiopian Revenue and customs authority, for their valuable information regarding these study.

\section{References}

1. Ayalew, Amare Birhanu, Biruhtesfa Asrade (2013) Review on food safety system: Ethiopian perspective. Afr J Food Sci 7(12): 431-440.

2. Anita, Neetu (2013) Hazards of new technologies in promoting food adulteration. J Env Sci Tox F Sci 5(1): 08-10.

3. Alauddin (2001) Food adulteration and society. Global research analysis international 1(7): 3-5.

4. Bradbear (2009) Production and trade of beeswax. In: Bees and their role in forest livelihoods.

5. Soares (2017) Comprehensive Reviews in Food Science and Food Safety. 16.

6. Gilberto (2007) Mass Spectrometry Laboratory. Nutrition Section, Department of Medical Clinical 2(3).

7. Pires J, Estevinho ML, Feas X, Cantalapiedra J, Iglesias A (2009) Pollen spectrum and physico-chemical attributes of heather (Erica sp.) honeys of north Portugal. J Sci Food Agric 89(11): 1862-1870.

8. Bogdanov S, Ruoff K, Oddo LP (2004) Physico-chemical methods for the characterisation of unifloral honeys: a review. Apidologie 35(1): S4-S17.

9. Sahinler N, Sahinler S, Gul A (2004) Biochemical composition of honeys produced in Turkey. J Apicult Res 43(2): 53-56.

10. Guler A, Bakan A, Nisbet C, Yavuz O (2007) Determination of important biochemical properties of honey to discriminate pure and adulterated honey with sucrose (Saccharum officinarum L.) syrup Food Chem 105(3): 1119-1125.

11. Ajlouni S, Sujirapinyokul P (2010) Hydroxymethylfurfuraldehyde and amylase contents in Australian honey. Food Chem 119(3): 1000-1005.

12. Bogdanov S, Martin P (2002) Honey authenticity: a review. Mitt Lebensm Hyg 93: 232-254

13. Bakalo, W Belay, Alebachew T (2016) Review on Medicinal Value of Honeybee Products: Apitherapy Advances in Biological Research 10(4): 236-247.

14. Guler A, Kocaokutgen H, Garipoglu AV, Onder H, Ekinci, et al. (2014) Detection of adulterated honey produced by honeybee (Apis mellifera 
L.) colonies fed with different levels of commercial industrial sugar (C(3) and C(4) plants) syrups by the carbon isotope ratio analysis. Food Chem 155: $155-160$.

\section{ISSN: 2574-1241}

DOI: $10.26717 /$ BJSTR.2020.32.005289

Yeshitila Eshete. Biomed J Sci \& Tech Res

(C) (P) This work is licensed under Creative

Submission Link: https://biomedres.us/submit-manuscript.php
15. Bogdanov S, Charriere JD, Imdorf A, Kilchenmann V, Fluri P (2002) Determination of residues in honey after treatments with formic and oxalic acid under field conditions. Apidologie 33(4): 399-409.

\begin{tabular}{ll} 
BIOMEDICAL & Assets of Publishing with us \\
RESEARCHES & - Global archiving of articles \\
& - Immediate, unrestricted online access \\
\hline
\end{tabular}

